\title{
Economic Assessment of New Herbicides Used to Fight the Weeds in Wheat
}

\author{
Vasko Nikolov Koprivlenski ${ }^{1}$, Maya Dincheva Dimitrova ${ }^{2}$ Ivan Stoyanov Jalnov², \\ Ilian Dimitrov Zheliazkov ${ }^{2}$, Plamen Ivanov Zorovski ${ }^{2}$ \\ ${ }^{1}$ Department of Management end Marketing, Faculty of Economics, Agricultural University, Plovdiv, Bulgaria \\ ${ }^{2}$ Department of Foundation of Agriculture, Faculty of Agronomy, Agricultural University, Plovdiv, Bulgaria
}

\section{Email address:}

koprivlenski@au-plovdiv.bg (V. Koprivlenski)

\section{To cite this article:}

Vasko Nikolov Koprivlenski, Maya Dincheva Dimitrova, Ivan Stoyanov Jalnov, Ilian Dimitrov Zheliazkov, Plamen Ivanov Zorovski. Economic Assessment of New Herbicides Used to Fight the Weeds in Wheat. Agriculture, Forestry and Fisheries.

Vol. 4, No. 2, 2015, pp. 66-70. doi: 10.11648/j.aff.20150402.17

\begin{abstract}
Within the period 2011-2014, at the experimental base of the Agricultural University - Plovdiv we conducted field experiments with new herbicides in wheat. Based on the obtained results, we made a summarized economic assessment of the chemical fight against weeds. We established the amount of production expenses needed for growing wheat in 10 tested variants including 9 treated with herbicidal preparations. It was found the critical levels of the yield for each variant as well as the factors determining them. The economic effectiveness of production has been analyzed using a system of various indicators: the value of the permanent and variable costs per unit of area; the level of the average yield; the value of the total revenue per unit of area; the amount of the profit from $1 \mathrm{ha}$; the prime cost of the production and the profitability rate. The highest average yield was obtained from the variants treated with herbicides: Axial 1 plus 050 EK (5180.60 kg/ha); Sekator OD (5200.00 kg/ha) and Pasifica VG $(5210,46 \mathrm{~kg} / \mathrm{ha})$. Upon the application of these herbicides, the rate of increase of the additional production from unit of area exceeds the rates of the investments made. This makes the use of these herbicides economically substantiated. With the exception of the untreated control sample, all other herbicides give good economic results from the production of wheat, a sufficient profit rate from unit of area and profitability ranging from $20 \%$ to $22 \%$.
\end{abstract}

Keywords: Wheat, Herbicides, Economic

\section{Introduction}

The high level of weed presence directly affects the growth, the development and the yield obtained from grain crops. This necessitates exercising control over weeds by using various selective herbicides for the purpose of restricting their negative influence on the production results.

Scientist from Pakistan (Mushtaq Ali et al., 2004 and Ashiq H. Sangi et al. 2012) have tested the influence of various herbicidal preparations on the final economic indices related to the production of wheat, comparing them to the untreated control sample. The results obtained from their experiments show that the use of herbicides increases the number of grains per one ear and the yield increases from $13,98 \%$ to $32,08 \%$. As a result, the economic indices - net returns from 1 ha and profit rate significantly exceed those of the control sample. Similar results are presented by Cheema, M. and Akhtar, M., 2005; Qazi, M. A. and al.. 2002; Ahmad, S., and al. 1995;
Ashiq H. S., and al. 2012; Jabbar, A., and al., 1999; Khan, M. and N. Haq, 1994; Sharar, M.S.,and al., 1994.

M. Sayili, and al. (2006) have made a comparative analysis regarding the use of herbicides in wheat under production conditions. They have studied 78 farms around Turkey, 70 of which use herbicides and 8 do not apply herbicidal preparations. The results from the comparative analysis show that the average yield of wheat treated with herbicides increases by $29,09 \%$ in case of irrigation and $10,53 \%$ if no irrigation has been applied, compared to the untreated control sample. When conducting irrigation, the amount of the profit from unit area for the farmers using herbicides is 181,47 dollars per ha and those not using herbicides obtain 28,06 dollars/ha, which is 6.5 times more. The profit threshold (the critical average yield) for which the wheat production ends without any profits or losses is $244,4 \mathrm{~kg} / \mathrm{ha}$ for the irrigated wheat and $176,40 \mathrm{~kg} /$ ha for the non-irrigated wheat. Similar studies regarding the effectiveness of the chemical fight 
against weeds in wheat have also been presented by Obst, A., 1981 and van Heems, T., 1985.

The area of the fields sown with wheat in Bulgaria varies from 1.1 million ha to 1.2 million ha. Every year, the fight against weeds is conducted using different herbicides (Aleksiev A. and al., 2003; Tityanov M. and al., 2009) but there is insufficient data about the economic effectiveness of the new herbicidal preparations.

The purpose of this study was to make aggregated economic assessment of the experimental results of the application of the herbicides to control weeds in wheat production. Implementation of the set objective passes through solving the following four interrelated tasks:

- Creation of Methodological Tools for Development and Assessment of Technological and Economic Estimates for the Test Culture;

- Accurate amount of the cost of production elements and technological units;
- Splitting the cost of fixed and variable based on carefully selected evaluation criteria.

- Determination of the critical level of the average yield and economic efficiency of the production of wheat.

\section{Materials and Methods}

\subsection{Conducting the Experiment}

Within the period 2011-2014 in the experimental field of the Agricultural University, Plovdiv, we made field experiments using new herbicides applied to the leaves during the vegetation period of the wheat, variety Diamand. The sowing during the three years of the experiment was performed on October 20-30. The experiments were made using the block method over an area of $21 \mathrm{~m}^{2}$ in four repetitions (As shown in Table 1).

Table 1. Variants of experiments.

\begin{tabular}{lll}
\hline Variants & Active substans & Dose \\
\hline 1. Derby super & $150,2 \mathrm{~g} / \mathrm{kg}$ florasulam $+300,5 \mathrm{~g} / \mathrm{kg}$ aminopiralid & $33 \mathrm{~g} / \mathrm{ha}$ \\
2. Arat & $500 \mathrm{~g} / \mathrm{kg}$ dicamba $+250 \mathrm{~g} / \mathrm{kg}$ tritosulfuron & $100 \mathrm{~g} / \mathrm{ha}$ \\
3. Laren $20 \mathrm{CG}$ & $200 \mathrm{~g} / \mathrm{kg}$ metsulfuron-methyl & $30 \mathrm{~g} / \mathrm{ha}$ \\
4. Secator OD & $106 \mathrm{~g} / 1$ amidosulfuron $+25 \mathrm{~g} / 1$ iodosulfuron & $100 \mathrm{~cm} / \mathrm{ha}$ \\
5. Lintur 70 WG & $41 \mathrm{~g} / \mathrm{kg}$ triasulfuron $+659 \mathrm{~g} / \mathrm{kg} \mathrm{dicamba}$ & $150 \mathrm{~g} / \mathrm{ha}$ \\
6. Axial 1 plus 050 EK & $45 \mathrm{~g} / 1$ pinoxaden $+5 \mathrm{~g} / 1$ florasulam & $1000 \mathrm{~cm}^{3} / \mathrm{ha}$ \\
7. Axial 050 EK & $50 \mathrm{~g} / 1$ pinoxaden & $600 \mathrm{~cm}^{3} / \mathrm{ha}$ \\
8. Pallas $75 \mathrm{WG}$ & $75 \mathrm{~g} / \mathrm{kg}$ piroxulam & $200 \mathrm{~g} / \mathrm{ha}$ \\
9. Pacifica WG & $30 \mathrm{~g} / \mathrm{kg}$ mezosulfuron $+10 \mathrm{~g} / \mathrm{kg}$ iodosulfuron & $350 \mathrm{~g} / \mathrm{ha}$ \\
10. Control & untreated & \\
\hline
\end{tabular}

The agrotechnical activities were conducted in accordance with the commonly used technology for wheat (processing of the soil, fertilization, sowing, rolling). The herbicides were applied using a knapsack sprayer and a solution of 300-400 $1 /$ ha.

\subsection{Methodological Tools for Development and Assessment of the Technological and Economic Estimates}

The amount of the production costs for growing wheat has been calculated on the grounds of a technological chart containing information about the physical volume and value of all necessary material and labour costs for growing and gathering the crop. The expenses for raw materials and other materials (seeds, fertilizers, preparations, fuel and lubricants, electricity and others) have been calculated on the grounds of their volume and unit price, on average for the period 2011-2013. The expenses for labour, mechanized activities (ploughing, cultivating, harrowing, transporting, fertilizing, spraying, gathering and others), additional costs, machine and tractor and transport expenses have been calculated on the grounds of the estimates valid for the Agricultural University - Plovdiv.

The value of the finished produce - the maize grain, has been calculated based on the average price for the period of the experiment 2011-2013.

\subsection{Splitting the Cost of Fixed and Variable Based on Carefully Selected Evaluation Criteria}

The fixed costs are notable for the following major characteristics:

- The manager can not change them in a short run;

- They do not depend on the size of production;

- With increasing the size of the produce they reduce in a unit of it;

- In a particular production it is difficult to calculate the fixed costs, because of which they are called yet indirect and are usually allocated as total economic costs.

The fixed costs include: the depreciation cost, costs of interest payments, maintenance charges as well as the overhaul, tax, tariff and insurance expenses.

The fixed costs include also the land rent, preliminarily specified rents of using the fixed assets, rents for different services and the labor cost (after signing the labor agreements).

The variable costs are investments that are directly used and transformed into final produce. Therefore, they are known as 
direct production cost. The main criteria to determine these costs as variable ones are:

- They can be managed or their size depends directly on the manager's decision;

- They directly influence the amount of the produce or are incurred only in case of carrying out production (herbicides, ets.);

- Their a per unit value remains relatively constant quantity under unchanged production conditions;

- They can be easily related to the production of one particular product (wheat, etc.)

\subsection{Methodological Tools for Determining the Critical Levels of the Yield and the Economic Thresholds of Efficiency in Variants of the Experiment}

The determination of the critical levels of the yield and the thresholds of efficiency in the production of wheat has been made using various indices shown in tables 3 and 4 (Koprivlenski, 2011).

The thresholds of efficiency, expressed through the critical level of the average yield for the separate variants, have been calculated using the formula:

$$
\mathrm{Q}_{\mathrm{BEP}}=\frac{F C}{p-V C_{1}}
$$

where:

$\mathrm{Q}_{\mathrm{BEP}}$ - the critical level of the average yield;

$\mathrm{FC}$ - total value of the stable costs;

$\mathrm{p}$ - average costs of the implementation;

$\mathrm{VC}_{1}$ - variable costs for unit of production.

The critical level of the average yield determines the amount of the yield for which the wheat production results in no profits or losses, after which each kilogram of the finished produce above the critical yield shall secure profits.

\section{Results and Discussion}

The amount and the structure of the production costs for growing wheat vary within a relatively narrow range for all the variants included in the experiment (As shown in Table 2).

Table 2. Production costs for growing wheat, lv/ha.

\begin{tabular}{llllllll}
\hline Variants & $\begin{array}{l}\text { Average yield, } \\
\mathbf{k g} / \mathbf{h a}\end{array}$ & $\begin{array}{l}\text { Material } \\
\text { costs /A/ }\end{array}$ & $\begin{array}{l}\text { Expenses } \\
\text { for tractor and transport /B/ }\end{array}$ & $\begin{array}{l}\text { Expenses for } \\
\text { manual labour /C/ } /\end{array}$ & $\begin{array}{l}\text { Direct costs } \\
\mathbf{I} / \mathbf{A}+\mathbf{B}+\mathbf{C} /\end{array}$ & $\begin{array}{l}\text { Additional } \\
\text { costs II }\end{array}$ & $\begin{array}{l}\text { Total costs } \\
\mathbf{I}+\mathbf{I I}\end{array}$ \\
\hline 1 & 5082 & 678.1 & 366.4 & 7.0 & 1051.5 & 218.7 & 1270.2 \\
2 & 4828 & 674.9 & 366.4 & 7.0 & 1048.3 & 218.2 & 1266.5 \\
3 & 4665 & 674.9 & 36.6 .4 & 7.1 & 1048.4 & 218.1 & 1266.5 \\
4 & 5200 & 679.9 & 366.4 & 7.1 & 1053.4 & 219.1 & 1272.5 \\
5 & 4935 & 677.9 & 366.4 & 7.0 & 1051.3 & 218.7 & 1270.0 \\
6 & 5186 & 751.9 & 366.4 & 7.2 & 1125.5 & 231.3 & 1356.8 \\
7 & 4067 & 698.9 & 366.4 & 7.0 & 1072.3 & 222.3 & 1294.6 \\
8 & 5153 & 696.4 & 366.4 & 7.0 & 1069.8 & 221.9 & 1291.7 \\
9 & 5214 & 727.9 & 366.4 & 7.0 & 1101.3 & 227.2 & 1328.5 \\
10. Control & 3522 & 663.9 & 366.4 & 6.6 & 1036.9 & 216.3 & 1253.2 \\
\hline
\end{tabular}

* The direct and indirect costs have been calculated based on the estimates for the Agricultural University

The most important factor determining this is the price of the used preparations and the doses applied to the separate variants. In relation to this, the direct production costs have a greater influence as the difference between the untreated control sample and the most material-consuming variant 6 is $8.54 \%$. Other factors affecting the amount of the costs include the selected technological variant and the volume of the finished product. As the volume of the finished product increases, the costs related to machines, tractors and transport also rise.

The drafted technological and economic calculations show that the variants with the highest level of production costs are those treated with the herbicides Axial 1 plus 050 EK and Pasifica WG. The total amount of material costs together with the additional charges for the two variants is $751.9 \mathrm{lv} / \mathrm{ha}$ and $727.9 \mathrm{lv} / \mathrm{ha}$, respectively. For the other variants, these values are $8-12 \%$ lower.

The structure of the general production costs is typical of the crops with a high level of mechanization of the production processes, such as wheat.

The highest average yield is obtained from the variants treated with the herbicides Axial 1 plus 050 EK $(5186.0 \mathrm{~kg} / \mathrm{ha})$, Secator OD (5200.0 kg/ha) and Pacifica WG (5214.0 kg/ha). The largest increase of the general production costs $-6.0 \%$ is registered between the control sample and the variant treated with the herbicide Pacifica WG. These two variants show the greatest difference in yield, reaching $48 \%$, which indicates that the growth rate of the additional production from unit area outstrips the investments made (As shown in Table 2 ).

The main results from the economic assessment of the tested herbicides used in the fight against weeds in wheat have been summarized in table 3 .

The amount of the production costs and the level of the average yield are the main factors affecting the economic effectiveness in the production of wheat between the separate variants of the experiment. The data in tables 2 and 3 indicates 
that the control sample has the lowest economic effectiveness.

Table 3. Economic efficiency and critical levels of the average yield in the production of wheat.

\begin{tabular}{|c|c|c|c|c|c|c|}
\hline Variants & $\begin{array}{l}\text { Average yield, } \\
\mathrm{kg} / \mathrm{ha}\end{array}$ & $\begin{array}{l}\text { Critical level of the average yield, } \\
\mathrm{kg} / \mathrm{ha}\end{array}$ & $\begin{array}{l}\text { Value of the total } \\
\text { produce, Iv/ha }\end{array}$ & $\begin{array}{l}\text { Net profit from } \\
1 \text { dka, lv/kg }\end{array}$ & $\begin{array}{l}\text { Prime cost of the } \\
\text { produce, lv/ha }\end{array}$ & $\begin{array}{l}\text { Profitability } \\
\text { rate, \% }\end{array}$ \\
\hline 1 & 5082 & 2430.0 & 1524.6 & 0.25 & 254.4 & 20.03 \\
\hline 2 & 4828 & 2727.5 & 1448.4 & 0.2 .6 & 181.9 & 14.36 \\
\hline 3 & 4665 & 2726.2 & 1399.5 & 0.27 & 133.0 & 10.50 \\
\hline 4 & 5200 & 2191.0 & 1560.0 & 0.24 & 287.5 & 22.59 \\
\hline 5 & 4935 & 2430.0 & 1480.5 & 0.25 & 210.5 & 16.57 \\
\hline 6 & 5186 & 2891.2 & 1555.8 & 0.26 & 199.0 & 14.67 \\
\hline 7 & 4067 & 5557.5 & 1220.1 & 0.31 & -74.5 & -5.75 \\
\hline 8 & 5153 & 2465.6 & 1545.9 & 0.25 & 254.2 & 19.68 \\
\hline 9 & 5214 & 2524.4 & 1564.2 & 0.25 & 235.7 & 17.74 \\
\hline 10. Control & 3522 & 21630.0 & 1056.6 & 0.36 & -196.6 & -15.69 \\
\hline
\end{tabular}

The low level of the yield from the untreated control sample as well as the comparatively high production costs are the reasons for the unsatisfactory value of the total production obtained from unit area - 1056.6 lv/ha (As shown in Table 2 ). With these levels, the overall production cannot provide net returns, in which case the production of this variant will lead to a loss and the profitability rate will be a negative value. A similar trend can be observed with variant 7 (Axial $050 \mathrm{EK}$ ), where the average yield is low and the level of the investments per unit area has been increased. The reason for this is the spectrum of activity of the herbicide, which destroys the annual monocotyledon weeds and the latter are not dominant among the wheat plants.

The cost price of production for variants 7 and 10 exceeds the purchase price of wheat and leads to negative economic indices for the aforementioned variants. For the remaining variants, the high yield provides normal returns of the investments and sufficient amount of the profit from 1 ha.

The highest economic effectiveness of the production was registered for variant 4 (Secator OD - 22,5\%), variant 1 (Derby super - 20,0\%) profitability and variant 8 (Pallas 75 WG - 19,68\%).

\section{Conclusion}

The use of herbicides in the fight against weeds is economically expedient considering the fact that they provide outpacing growth rates of the overall revenue from the production. In other words, the use of herbicides is justified when they cause a faster rate of increase in additional revenue, resulting in total revenues are higher or at least equal to variable costs.

For a short period of time to cover fixed costs can be "delayed" because in the short term they are not affected by the volume of production. Furthermore, we found out that the value of fixed costs per unit of output fell by any excess product. Therefore, for the fixed costs, in the short term, growth in the volume of production is always justified.

Therefore, the criterion for assessing the appropriateness of wheat production is the ratio between total revenue and total variable costs. The difference between them must be positive or zero, to justify the production of wheat.
All the variants treated with herbicides provide high economic results in the production of wheat, sufficient amount of the profit from unit area and profitability rate ranging from 10,50 to $22,59 \%$. The critical level of the yield from these variants varies from 42 to $58 \%$ of the production actually obtained from unit area.

The specified thresholds of effectiveness for all variants treated with herbicides provide high competitiveness and profitability of the crops, which allows for normal reproduction.

\section{Acknowledgements}

This study was funded from the Research Fund of Ministry of Education and Science, Bulgaria: Project number DDVU 02/82 "Agro-ecological Assessment of New chemical Products for Plant Protection in Modern Agriculture".

\section{References}

[1] Ahmad S, Sarwar M, Tanveerand A, Khaliq A, (1995). Efficacy of some weedicides in controlling P. minor Retz. In: Wheat. Proc. $4^{\text {th }}$ All Pakistan WeedSci. Corf., Faisalabad. 26-27 March, 1994, 89-94.

[2] Aleksiev A., Tonev T, Tityanov M, (2003). Economik Analysis of the Effekt of the Chemical Weed Control in Wheat Crops. Agricultural Economiks and Management, 4, 76-83.

[3] Sangi AH, Aslam M. Javed S, Khalid L, (2012). Efficacy and Economics of Mixing Different Herbicides for Controlling Broad and Narrow Leaved Weeds in Wheat. J. Agric. Res., 50 (1), 79-87.

[4] Ashraf MY, Baig NA, Khan MA, (1989). Chemical weed control in wheat (Triticum aestivum L). Pakistan J. Agri., Agri. Engg. and Vet. Sci., 5, 21- 4.

[5] Cheema MS, Akhtar M, (2005). Efficacy of different post emergence herbicides and their application methods in controlling weeds in wheat. Pak. J. Weed Sci. Res.,11(9-12), 23-29.

[6] Jabbar A, Saeed M, Ghaffar A, (1999). Agro-chemical weed management in wheat. Pakistan J. Agri. Sci., 36, 33-8. 
[7] Khan M, Haq N, (1994). Effect of post emergence herbicides on weed control and wheat yield. J. Agric. Res., 32, 253-9.

[8] Koprivlenski V, (2011). Production costs and thresholds of efficiency in plant-growing, Academic publishing house of the Agricultural University, Plovdiv (Bg), 17 - 36.

[9] Sayili M, Akca H, Önen H, (2006). Economic analysis of herbicide usage in wheat fields. Journal of Plant Diseases and Protection, 755-760.

[10] Mushtaq A, Sabir S, Din QM, Ali MA, (2004). Efficacy and Economics of Different Herbicides Against Narrow Leaved Weeds in Wheat. International Journal of Agriculture \& Biology, 647-651.

[11] Mushtaq A, Shahzad S, Din QM, Ali MA, 2004. Efficacy and economics of different herbicides against narrow leaved weeds in wheat. Int. J. Agri. Biol. 6(4): 647-651.

[12] Obst A, (1981). Chemical control in intensive wheat cultivation. In: Kommedahl, T. (ed): Proceedings of Symposia IX International Congress of Plant Protection, 5-11 August 1979, Entomological Society of America, 448-451.

[13] Qazi, MA, Ullah AS, Ali A, (2002). Weed management-hand weeding vs chemical weed control in wheat. Balochistan J. Agric. Sci., 2, 39-42.

[14] Sharar MS, Sharif M, Shah SH, Tanveer A, (1994). Efficacy of some herbicides in controlling weeds in wheat (Triticum aestivum L.). Proc. $4^{\text {th }}$ All Pakistan Weed Sci. Conf., Faisalabad. 26-27 March, 18.

[15] Tityanov M, Tonev T, Mitkov A, (2009). New Opportunities for Efficient Chemical Control of Weeds in Wheat. Plant Science, vol. XLVI, 154-160.

[16] Tmo, Statistical data (www.tmo.gov.tr), 2005

[17] Heemst DJ, (1985). The influence of weed competition on crop yield. Agricultural Systems, 18, 81-93. 